\author{
Михайлова Ірина \\ здобувач вищого освітнього ступеня «Магістр», \\ спеціальності «Психологія» \\ Рівненського державного гуманітарного університету \\ ORCID iD 0000-0003-0514-505X \\ DOI https://doi.org/10.35619/prap_rv.vi13.126
}

\title{
АНАЛІЗ ЕФЕКТИВНОСТІ ПРИЙНЯТТЯ «СИЛЬНОЇ ПОЗИ» ЯК ЗАСОБУ КОРЕКЦІЇ НИЗЬКОГО РІВНЯ САМООЦІНКИ
}

\begin{abstract}
Анотація. $У$ статті розглянуті особливості Я-тілесного як підструктури самосвідомості. Описані наступні компоненти самосвідомості: когнітивний характеризує зміст уявлень індивіда про себе; афективний - розкриває, як люди сприймають себе, які емочії та почуття вони мають щзодо себе; поведінковий - визначає можливість саморегуляиії, здатність особистості приймати самостійні рімення, керувати своєю поведінкою, контролювати ї̈, відповідати за свої дії. Розглянутий їх взаємозв'язок з Ятілесним. Проаналізовані останні дослідження та публікації вітчизняних та зарубіжних науковиів стосовно Я-тілесного. Наведено декілька трактувань терміну "Я-тілесне» та подано розширене визначення иьому поняттю. Розглянута структура Я-тілесного, яка складається з наступних компонентів: когнітивного - знання про власне тіло, як про організм; емоційного - сприйняття, установка, оцінка, уявлення, пов'язані з власною зовнішністю і функціями тіла; функціонального - забезпечує регуляцію положення частин тіла, контроль $і$ корекцію рухового акту з залежністю від зовнішніх умов. Особлива увага приділена зв'язку афективного компоненту самосвідомості 3 оиінкою власної привабливості. Описано, як самооцінка людини проявляється у ї̈ жестах та міміці, як виявляють емоиії представники різних країн та племен. У статті розглянуте поняття «сильних поз» та проведене і описане емпіричне дослідження впливу прийняття «сильної пози» на рівень самооцінки.
\end{abstract}

Ключові слова: Я-тілесне, самосвідомість, афективний компонент самосвідомості, самооцінка, образ тіла, «сильні пози».

Постановка проблеми. Актуальні проблеми суспільства сприяють активізації вивчення Я-тілесного як підструктури самосвідомості. Самосвідомість відображає усвідомлення індивідом того, яким він є, якими якостями володіє, як ставляться до нього інші люди, чим зумовлене це ставлення. Вона є складною психологічною системою, що розвивається упродовж усього життя людини (Павелків, Цигипало, 2008, с. 202). У іiі структурі виділяють три компоненти: когнітивний - характеризує зміст уявлень індивіда про себе; афективний - виявляє, як сприймає людина саму себе, які емоції та почуття вона має стосовно себе; поведінковий - визначає можливість саморегуляції, здатність особистості приймати самостійні рішення, керувати своєю поведінкою, контролювати іï, відповідати за свої вчинки (Боришевський, 2004, с. 583). Самосвідомість вважають «ядром особистості», адже вона регулює всі сфери життя людини (Майєрс, 2016, с. 111), від неї залежить самооцінка особистості, рівень іiі домагань, впевненість у собі та можливість сповна реалізувати свій потенціал.

В умовах сучасного суспільства при дослідженні самосвідомості особливу увагу приділяють іï підструктурі - Я-тілесному (Титаренко, 2010, с. 15). Мовою тіла, власними жестами та мімікою людина несвідомо демонструє афективний компонент самосвідомості, тобто рівень самооцінки та самоповаги. Упізнати невпевнену у собі особистість 3 заниженою самооцінкою можливо навіть за поставою - для таких людей характерні закриті пози, сутулість, намагання займати менше простору та бути непомітними. Окрім того, образ власного тіла справляє вплив на афективний компонент самосвідомості. Задоволення власною зовнішністю може підвищити рівень самооцінки, у той час як неприйняття, 
негативна установка до власного Я-Тілесного здатні зруйнувати позитивне ставлення людини до себе, що може навіть сприяти виникненню депресії, нервової анорексії, булемії. Усе це свідчить про те, що для сучасної людини їі зовнішність має вагоме, часом навіть надмірно перебільшене значення, а отже, сама підструктура Я-тілесне, а особливо його афективний компонент, ставлення до власного тіла, відіграє у самосвідомості одну 3 ключових ролей (Агарева, 2011, с.137).

Аналіз останніх досліджень і публікацій. Існує багато поглядів на трактування терміну «Я-тілесне». Початок системного аналізу закладено в роботах представників психотерапевтичних шкіл Фрейда і Кречмера, а також в тілесно-орієнтованих підходах сучасної школи психотерапії Райха, Лоуена, Александера, Фельденкрайза, Рольфа. Численні дослідження довели, що Я-тілесне відіграє значну роль у формуванні самосвідомості особистості. Наприклад, Фельденкрайз дослідив взаємозалежність Я-тілесного і самооцінки. Він показав, що характер поведінки людини може відображати механізми компенсації уявної недосконалості тіла (Клейман, 2016, с.223).

Образ тілесного «Я» можна розглядати і з позиції сприйняття зовнішніх форм тіла, представленої трьома підходами: тіло як носій особистісних і соціальних значень, в яких вивчається емоційне ставлення особистості до своєї зовнішності; тіло як об'єкт, наділений певною формою; акцент в дослідженні ставиться на когнітивно-компоненте його сприйняття; тіло і його функції як носії певного символічного значення ( Бескова та Тхостов, 2004, с.135).

Науковці Воробйов, Киященко, Соколова розглядають образ тілесного «Я» як психічне утворення, що включає в себе «явища свідомості»: традиції, забобони, плани, бажання, потреби. Ними відзначається взаємозалежність культури тіла і культури думки; в їх єдності, «утворюється цілісність», доводиться домінанта психічного по відношенні до соматичного, яка опосередкована культурою соціуму. У дослідженнях образу фізичного «Я» простежується взаємозв'язок і взаємовплив афективних і когнітивних процесів, їх роль у становленні особистості. Соколова виділила три напрямки досліджень образу тілесного «Я» (Соколова, 2001, с. 94). Відповідно до першого підходу, образ тіла або інтерпретується в контексті аналізу активності певних нейронних систем, і в даному напрямку такі поняття, як «схема тіла» і «образ тіла», тотожні один одному, або ці поняття мають самостійне значення. «Схема тіла» характеризує стійке знання людини про своє тіло, в той час як «образ тіла» постає як ситуативна психічна репрезентація власного тіла і розглядається як результат психічного відображення. Представники другого підходу вважають, що «образ тіла» $\epsilon$ результатом психічного відображення. Вони розрізняють «абстрактне тіло», тобто тіло концептуальне, і «власне тіло», побудоване на сприйнятті свого тіла. Прихильники третього напряму «образ тіла» розглядають як складну комплексну єдність сприйняття, установок, оцінок, уявлень, пов'язаних з тілесної формою і функціями. Виділяють чотири рівні в моделі образу тіла: схема тіла, тілесне «Я», тілесне уявлення, концепція тіла. Схема тіла свідчить про стабільність сприйняття тіла в просторі. Характер оцінки тілесного «Я» визначає рівень фізичної самоідентичності. Тілесне уявлення відображає фантазії людини в своєму тілі і його асоціації. Концепція тіла з'єднується з раціональним мисленням і відповідає формальному знанню в тілі (Леви, 2004, с. 297).

Сприйняття і оцінка тілесних форм носить емоційне забарвлення і здійснюється на двох рівнях. Перший рівень оцінки пов'язаний з порівнянням своїх зовнішніх даних із зовнішніми даними інших людей, другий - 3 переживанням задоволеності від сприйняття форм і якостей своєї тілесної самості, яка відображає ступінь відповідності зовнішніх даних вимогам, що пред'являються себе особистістю (Майєрс, 2016, с. 163).

Таким чином, можна виокремлювати два типи сприйняття - ставлення суб'єкта до свого образу тілесного «Я»: образ тілесного «Я» стосовно інших в порівнянні $з$ нормами і вимогами соціального оточення; образ тілесного «Я» стосовно свого сприйняття і розуміння сенсу свого існування незалежно від оцінок і суджень інших.

Підсумовуючи усі наведенні концепції, можна визначити наступну структуру Ятілесного, яка складається з трьох компонентів:

- когнітивного - знання про власне тіло, як про організм;

Випуск 13, 2019 Збірник наукових праць РДГУ. 
- емоційного - сприйняття, установка, оцінка, уявлення, пов'язані з власною зовнішністю і функціями тіла;

- функціональний - забезпечує регуляцію положення частин тіла, контроль i корекцію рухового акту з залежністю від зовнішніх умов.

Тобто, Я-тілесне - знання про власне тіло, ставлення до власного тіла, і регуляція рухів власного тіла.

Алан і Барбара Пізи описали те, як самосвідомість проявляється через Я-тілесне. Впевнені у собі, у своїх думках та діях люди стоять, розставивши ноги на ширину розправлених плечей, їх хода стрімка й швидка, з твердим кроком і піднятою головою. Їм характерні відкриті жести, наприклад, повернуті до співрозмовника долоні, вони без остраху чи сором'язливості дивляться людям в очі. У той час як невпевнені люди переминаються 3 ноги на ногу, ходять шархаючи, згинаючи коліна та дивлячись собі під ноги. Їх сутулі та підняті плечі створюють враження, ніби людина намагається стати меншою та сховати шию від співрозмовника. Також їм характерні захисні жести: вони схрещують руки на грудях, накидають ногу на ногу або перехрещують їх в області щиколотки (Піз та Піз, 2015, с. 381).

Досліджуючи емоційне реагування людей різних національностей, Пол Екман відзначив, що жителі різних країн та навіть племен, які не проходять ту ж соціалізацію, що діти цивілізованих держав, виявляють емоції однаково: при радості вони посміхаються, при здивуванні вони округляють очі, при обурені чи невдоволені суплять брови і тому подібне (Екман, 2010, с. 25). Отже, Я-тілесне виражає емоції людини, іiі почуття, а також іiі внутрішній стан, впевненість у собі та загальні уявлення про свої можливості, здібності та силу.

Таким чином вже неодноразово було доведено, що думки людини та іiі емоції впливають на їі тіло, проте американська психологиня Емі Кадді вирішила знайти відповідь на наступне питання: «Ми знаємо, що наш розум може впливати на наше тіло. Та чи може наше тіло вплинути на наш розум?» ( Carney, Cuddy, Yap, 2010, p.110). Жінка отримала відповідь на це питання шляхом дослідження впливу «сильних поз». Кадді здійснила експеримент як невербальні пози влади (тобто експансивні, відкриті, космічні позиції) впливають на почуття людей, поведінку та рівень гормонів. Зокрема, вона стверджувала, що прийом положень тіла, пов'язаних із домінуванням та силою («силою позиціонування») протягом всього лише двох хвилин, може збільшити рівень тестостерону, знизити кортизол, збільшити апетит до ризику та підвищити ефективність роботи в інтерв'юванні. Це було широко повідомлено в популярних ЗМІ. Був зроблений наступний висновок: «Якщо ти діятимеш владно, ти почнеш думати владно».

У дослідженні встановлено, що суб'єкти, які повинні були стояти або сидіти в певних положеннях - поклавши ноги на стіл, - повідомляли про більш сильне почуття влади «після позування, ніж раніше». Ще більш переконливим, ніж це, було те, що в дослідженні вимірювалися фактичні фізіологічні зміни в результаті пози: рівні тестостерону у випробовуваних підвищувалися, а рівні кортизолу, пов'язані зі стресом, знижувалися ( Carney, Cuddy, Yap, 2010, p.113). Не зважаючи на популярність цієї гіпотези, з 2014 року дослідження Емі Кадді зазнало критики. Науковиця Єва Ранехіль та інші дослідники намагалися повторити експеримент залучивши більшу кількість учасників , та виявили, що «сильні пози» хоч і породжують суб'єктивне почуття сили, та не впливають на гормони (Ranehill and other, 2015, p. 71). Тобто вплив тіла на самосвідомість не був однозначно доведений.

Метою дослідження $є$ аналіз ефективності прийняття «сильної пози» як засобу корекції низького рівня самооцінки.

Виклад основного матеріалу дослідження. У дослідженні взяли учні віком 16-17 років. Першим завданням було продіагностувати рівень самооцінки респондентів. Для цього була використана методика для визначення самооцінки Дембо та Рубінштейн. Також була додатково використана анкета задля виявлення ставлення учнів до власної зовнішності. Оскільки вона створювалась на основі методики Дембо та Рубінштейн, у ній також було визначено дев'ять позицій задля оцінки особистої привабливості: 1. найбільш гарні; 2. дуже 
гарні; 3. гарні; 4. більш-менш гарні ; 5. середньої краси; 6. більш-менш не гарні; 7. не гарні; 8. дуже не гарні; 9. страшні

Після опрацювання результатів були отримані наступні дані. Високий рівень самооцінки (учні обирали своє місце на сходинках 1 та 2, а також середнє арифметичне значення по всім шкалам було менше трьох) був виявлений у $12,5 \%$ учнів. Середній рівень самооцінки (учні обрали своє місце на сходинках 3-5, а також середнє арифметичне значення по всім шкалам від 3 до 5) був виявлений у 83,4\% респондентів. Низький рівень самооцінки ( місце переважно на 6-7 сходинка, середнє арифметичне значення нижче 5) виявлений у 4,1\%. Значних різниць між місцями, які обирали учні на різних шкалах, виявлено не було. Після аналізу отриманих результатів, було виявлено, що респонденти, задоволені своєю зовнішністю та здоров'ям, обирали високі позиції й з інших шкал.

Другим завданням було продіагностувати образ власного тіла учнів. Для цього був використаний опитувальник образу власного тіла Скугаревського та Сивухи. Після опрацювання результатів були отримані наступні дані. У 8,33\% респондентів позитивне ставлення до власного тіла. Приймають власне тіло 87,57\% учнів. Негативне ставлення до власного тіла наявне лише у 4,1\%. Отже, загалом у класі переважає позитивне ставлення до власного тіла. Позитивне ставлення до власного тіла притаманне респондентам, які за методикою Дембо і Рубінштейн мають високий рівень самооцінки. Учні, які за вказаною методикою мають низьку самооцінку, також негативно ставляться до власного тіла, вони не люблять власне тіло, відчувають сором за власне тіло у присутності певних людей та незручність у зв'язку з власною зовнішністю.

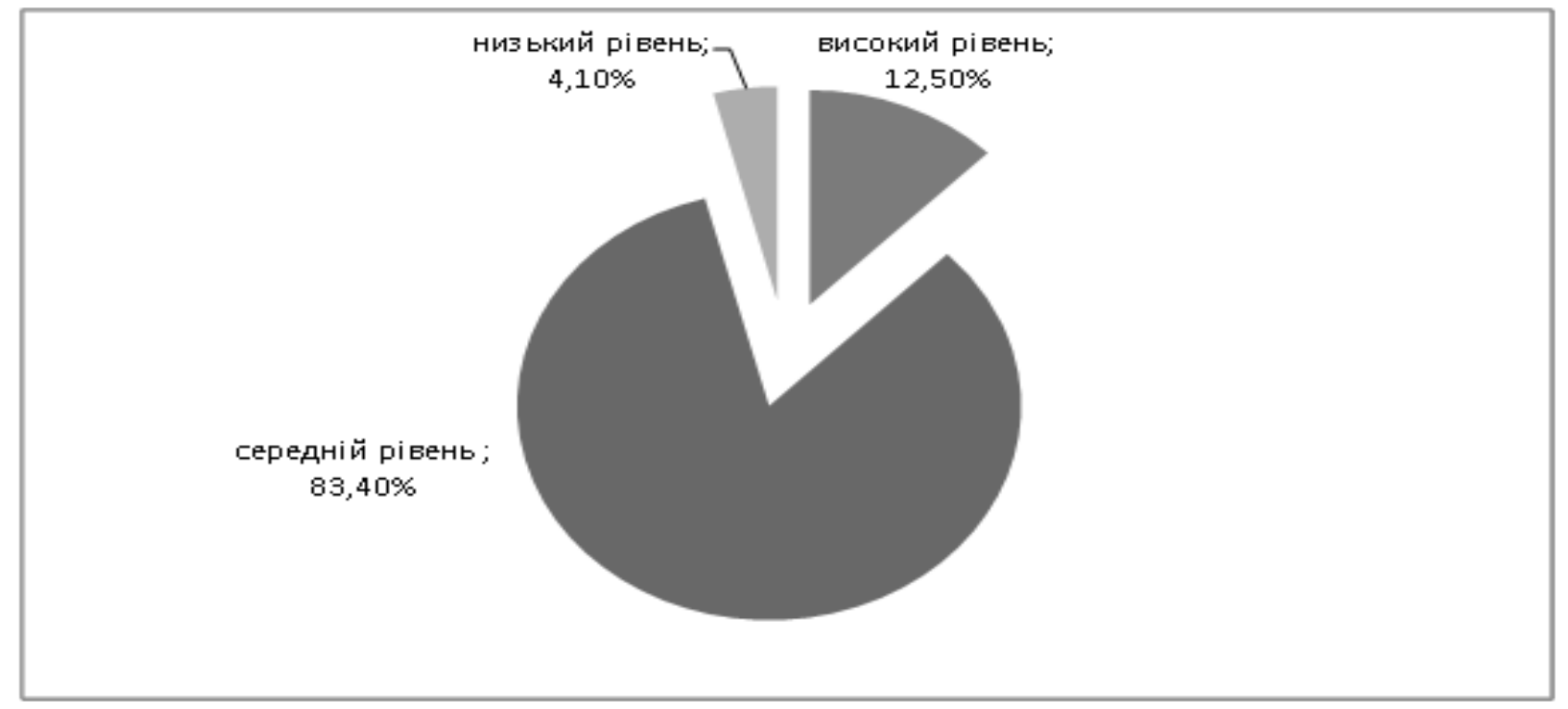

Рис. 1. Рівень самооцінки учнів за методикою Дембо - Рубінштейн (до
експерименту)

Отже, аналіз отриманих результатів підтверджує, що самооцінка може бути прямо пов'язана зі ставленням до власного тіла. Ті люди, які задоволені своєю зовнішністю, вагою, також позитивно оцінюють і інші власні якості.

Після дослідження самооцінки респондентів та їх образу тіла, був проведений експеримент, у ході якого учні мали стояти у «сильній позі» - ноги розставлені на ширині плеч, руки вперті в боки - протягом двох хвилин. Після того, як минуло дві хвилин, респонденти сіли на місця й пройшли тест-опитувальник «Визначення рівня самооцінки» С. В. Ковальова. Особлива увага була звернута на відповіді, що стосувались тверджень оцінки власної зовнішності та впевненості у собі: 8 - зовнішній вигляд інших куди краще, ніж мій; 12 - як шкода, що мені не вистачає впевненості в собі; 14 - я занадто скромний; 20 - я злегка ніяковію; 25 - я відчуваю себе скутим. Після прийняття «сильної пози» були помітні позитивні зрушення щодо впевненості у собі в більшості учнів. Вони частіше обирали відповіді «рідко» та «іноді», і навіть щодо власної зовнішності стали більш лояльними. Лише 
учні, що продемонстрували низький рівень самооцінки відповіли, що їх зовнішність «часто» гірша за зовнішність інших. Інші ж знову ж таки надали перевагу відповідям «рідно» та «іноді».

Також при інтерпретації результатів проходження тесту-опитувальника Ковальова було виявлено, що збільшилась кількість учнів 3 високою самооцінкою, порівняно 3 кількістю, яка була до прийняття сильної пози. 3 високим рівнем самооцінки було виявлено 20,8\%, з середнім 75,1\%, з низьким - 4,1\%.



Рис. 2. Рівень самооцінки учнів за методикою Ковальова (після експерименту)

Висновки та перспективи подальших розвідок. Отже, актуальні проблеми суспільства сприяють активізації вивчення Я-тілесного як підструктури самосвідомості. Почуття людини стосовно неї самої та емоції проявляються через Я-тілесне (Алан і Барбара Піз, Пол Екман), як і тілесно-орієнтована терапія може вплинути на суб'єктивне відчуття власної влади та сили (Емі Каді). Фельденкрайз довів взаємозалежність Я-тілесного і самооцінки: характер поведінки людини може відображати механізми компенсації уявної ущербності тіла.

Після проведення дослідження було підтверджено, що Я-тілесне та самооцінка $є$ взаємопов'язані. Учні, які задоволені власним здоров'ям та власною зовнішністю також $\epsilon$ задоволеними i іншими своїми характеристиками, такими як розум та характером. Респонденти, які проявили невдоволеність власним здоров'ям, зовнішністю, мають низький рівень самооцінки. Після проведення експерименту, прийняття респондентами «сильної пози» упродовж двох хвилин, було виявлено, що число тих, у кого високий рівень самооцінки, збільшилося. Однак для тих, хто мав низький рівень самооцінки, метод виявився недієвим, не було виявлено покращення.

Перспективами для подальших досліджень $є$ виявлення закономірності чи іiі відсутності між дієвістю методу і особливостями характеру, темпераменту, локусу контролю респондентів, тобто знаходження причин, які впливають на результативність прийняття «сильної пози».

\section{СПИСОК ПОСИЛАНЬ}

Агарева, М. (2011). Образ телесного Я ребенка как педагогическая проблема. Теоретические и методологические проблемы современного образования (с. 134-146). Москва: Известия ВГПУ.

Бескова, Д., Тхостов, А. (2004). Психология телесности: между душой и телом. Москва: ACT.

Боришевський, М. (2012). Особистість у вимірах самосвідомості. Київ: Еллада. 
Клейнман, П. (2016). Психологія 101: Факти, теорія, статистика, тести й таке інше. Харків: Книжковий клуб "Клуб сімейного дозвілля".

Леви, Т. (2004). Психология телесности в ракурсе личностного развития. Москва.

Майерс, Д. (2016). Социальная психология. Санкт-Петербург: Питер

Павелків, Р., Цигипало, О. (2008). Дитяча психологія. Київ: Академидав.

Піз, А., Піз, Б. (2015). Мова рухів тіла. Київ: ТОВ "Компанія ОСМА".

Соколова, Е. (2001). Общая психотерапия. Москва: Тривола.

Титаренко, Т. (2010). Життєвий шлях особистості в постмодерністському дискурсі. Психологія особистості, 1, 11-18.

Экман, П. (2010). Психология эмоций. Я знаю, что ты чувствуешь. Санкт-Петербург: Питер.

Carney, D., Cuddy, A. J. C., \& Yap, A. (2010). "Power posing: Brief nonverbal displays affect neuroendocrine levels and risk tolerance". Psychological Science, 21 (10): "The Top 10 Psychology Studies of 2010" by Halvorson.

Ranehill, E., Dreber, A., Johannesson, M., Leiberg, S., Sul, S., \& Weber, R. A. (May 26, 2015). "Assessing the Robustness of Power Posing: No Effect on Hormones and Risk Tolerance in a Large Sample of Men and Women" (PDF). Psychological Science, 26 (5), 653-656.

\section{REFERENCES}

Agareva, M. (2011). Obraz telesnogo Ja rebenka kak pedagogicheskaja problema [The image of the bodily self of the child as a pedagogical problem]. Teoreticheskie i metodologicheskie problemy sovremennogo obrazovanija (s. 134-146). Moskva: Izvestija VGPU. [in Russian].

Beskova, D., \& Thostov A. (2004). Psihologija telesnosti: mezhdu dushoj i telom [Body Psychology: Between Soul and Body]. Moskva: AST. [in Russian].

Borishevs'kij, M.( 2012). Osobistist' u vimirah samosvidomosti [Personality in the dimensions of self-awareness]. Kyiv: Ellada. [in Ukrainian].

Klejnman, P. (2016). Psihologija 101: Fakti, teorija, statistika, testi j take inshe [Psychology 101: Facts, Theory, Statistics, Tests, and more]. Kharkiv: Knizhnij klub "Klub simejnogo dozvillja". [in Ukrainian].

Levi, T. (2004). Psihologija telesnosti v rakurse lichnostnogo razvitija [The psychology of physicality from the perspective of personal development]. Moskva. [in Russian].

Majers, D. (2016). Social'naja psihologija [Social Psychology]. Sankt-Peterburg: Piter. [in Russian].

Pavelkiv, R., \& Cigipalo, O. (2008). Ditjacha psihologija: navch. posib [Child psychology: a textbook]. Kyiv: Akademvidav. [in Ukrainian].

Piz, A., \& Piz, B. (2015). Mova ruhiv tila [Body language]. Kyiv: TOV "Kompanija OSMA". [in Ukrainian].

Sokolova, E. (2001). Obshhaja psihoterapija [General psychotherapya]. Moskva : Trivola. [in Russian].

Titarenko, T. (2010). Zhittevij shljah osobistosti v postmodernists'komu diskursi [Personal life path in postmodern discourse]. Psihologija osobistosti, 1, 11-18. [in Ukrainian].

Jekman, P. (2010). Psihologija jemocij. Ja znaju, chto ty chuvstvuesh' [Psychology of emotions. I know what you feel]. Sankt-Peterburg: Piter. [in Russian].

Carney, D., Cuddy, A. J. C., \& Yap, A. (2010). "Power posing: Brief nonverbal displays affect neuroendocrine levels and risk tolerance". Psychological Science. 21 (10): "The Top 10 Psychology Studies of 2010" by Halvorson. [in English].

Ranehill, E., Dreber, A., Johannesson, M., Leiberg, S., Sul, S., \& Weber, R. A. (May 26, 2015). "Assessing the Robustness of Power Posing: No Effect on Hormones and Risk Tolerance in a Large Sample of Men and Women" (PDF). Psychological Science, 26 (5), 653-656. [in English]. 


\title{
ANALYSIS OF THE EFFECTIVENESS OF TAKING A "STRONG POSE" ASA A MEANS OF CORRECTING LOW LEVELS OFSELF-ESTEEM
}

Iryna Mykhailova

graduate student,

Rivne State University of the Humanities

ORCID iD 0000-0003-0514-505X

DOI https://doi.org/10.35619/prap_rv.vi13.126

\begin{abstract}
The article deals with the features of the self-bodily as a substructure of selfconsciousness. A definition of self-awareness was provided. Self-awareness reflects the individual's awareness of what he is, what qualities he possesses, how other people treat him, what his attitude is. The following components of self-awareness are described: cognitive - characterizes the content of the individual's ideas about himself; affective - reveals how people perceive themselves, what emotions and feelings they have about themselves; behavioral - defines the possibility of selfregulation, the ability of the individual to make independent decisions, to manage their behavior, to control it, to be responsible for their actions. Particular attention is paid to the interrelation of the affective component and the self-bodily. Recent research and publications by leading scholars on the self-body are analyzed. Several interpretations of the term "I-bodily" are given and an extended definition is given: self-bodily - knowledge of one's own body, attitude to one's own body, and regulation of one's own body movements.

The article describes three components of the self-body: cognitive - knowledge of one's body as an organism; emotional - the perception, installation, evaluation, ideas related to one's own appearance and body functions; functional - provides regulation of the position of body parts, control and correction of the motor act with dependence on external conditions. The structure of the self-bodily is considered. It describes how a person's self-esteem manifests itself in his gestures and facial expressions, how emotions are expressed by representatives of different countries and tribes. Gestures of confidence and insecurity, closedness and openness are described. The research of the scientists Alan and Barbara Pease and Paul Ekman is analyzed. The article deals with the notion of "strong poses", their research.

The experiment of social psychologist Amy Kadi on the effect of body posture on the level of hormones in the body is described. An empirical study of the impact of taking a "power poses» on the level of self-esteem was conducted and described.
\end{abstract}

Key words: Self-body, self-consciousness, affective component of self-consciousness, selfesteem, body image, "power poses». 